\title{
Investigation of the role of Ras and other signaling kinases on the regulation of pyruvate dehydrogenase complex activity
}

\author{
Antonio Garcia-Trinidad*, Nicky Whalley, Susan Critchlow \\ From Metabolism, Diet and Disease 2014: Cancer and metabolism \\ Washington DC, USA. 28-30 May 2014
}

Mutations in K-Ras commonly occur in colorectal, pancreatic and lung cancer, whereas mutations in BRAF are frequently found in melanomas. In past years, several studies have pointed to the role of Ras/Raf in the control of several metabolism pathways including glycolysis, mitochondrial respiration and glutamine metabolism [1-4]. The PDC complex is one of the central enzymes in the aerobic metabolism which converts the pyruvate produced during the glycolysis into Acetyl CoA used in the TCA cycle. In this work we show a pronounced sensitivity to PDHK-4 depletion in different mutant K-Ras cell lines, resulting in an increase of cell death and inhibition of cell growth in colorectal and lung tumor cell lines. Interestingly, cells expressing wild type K-Ras were signifinantly resistant to PDHK-4 depletion. This sensitivity in mutant Ras cells was correlated with a decrease in ERK phosphorylation, suggesting a possible inactivation in the Ras signaling pathway after PDHK-4 knock-down. Further studies will allow us to understand the biological mechanism by which Ras function is affecting the metabolic pathways involved in the regulation of PDC complex in cancer cells. Understanding the link between the PDC complex and Ras could be relevant to target cancer progression more effectively.

Published: 28 May 2014

\section{References}

1. Yun J, Rago C, Cheong I, Pagliarini R, Angenendt P, Rajagopalan H, Schmidt K, Willson JK, Markowitz S, Zhou S, Diaz LA Jr, Velculescu VE, Lengauer C, Kinzler KW, Vogelstein B, Papadopoulos N, Phillips DH, Garte S: Glucose deprivation contributes to the development of KRASpathway mutations in tumor cells. Science 2009, 325:1555-1560.
2. Ying $\mathrm{H}$, Kimmelman $\mathrm{AC}$, Lyssiotis $C A$, et al: Oncogenic Kras maintains pancreatic tumors through regulation of anabolic glucose metabolism. Cell 2012, 49:656.

3. Son J, Lyssiotis CA, Ying H, et al: Glutamine supports pancreatic cancer growth through a Kras-regulated metabolic pathway. Nature 2013, 496:101-105.

4. Yumin Hu, Weiqin Lu, Gang Chen, et al: K-rasG12V transformatio leads to mitochondrial dysfunction and a metabolic switch from oxidative phosphorylation to glycolysis. Cell Research 2012, 22:399-412.

doi:10.1186/2049-3002-2-S1-P20

Cite this article as: Garcia-Trinidad et al: Investigation of the role of Ras and other signaling kinases on the regulation of pyruvate dehydrogenase complex activity. Cancer \& Metabolism 2014 2(Suppl 1): P20.

Submit your next manuscript to BioMed Central and take full advantage of:

- Convenient online submission

- Thorough peer review

- No space constraints or color figure charges

- Immediate publication on acceptance

- Inclusion in PubMed, CAS, Scopus and Google Scholar

- Research which is freely available for redistribution 